\title{
TNF Receptor-Associated Factor 3
}

National Cancer Institute

\section{Source}

National Cancer Institute. TNFReceptor-Associated Factor 3. NCI Thesaurus. Code C96379.

TNF receptor-associated factor 3 ( $568 \mathrm{aa}, \sim 64 \mathrm{kDa}$ ) is encoded by the human TRAF3 gene. This protein is involved in the induction of apoptosis and signaling. 